\title{
Antibody Isotype Responses to Egg Antigens in Human Chronic Schistosomiasis Mansoni Before and After Treatment
}

\author{
Yara M Gomes/+ , Valéria RA Pereira, Mineo Nakazawa, Ulisses Montarroyos*, \\ Wayner V Souza*, Frederico GC Abath
} Departamento de Imunologia *Núcleo de Informação Científica e Comunicação, Centro de Pesquisas Aggeu Magalhães-Fiocruz,
Av. Moraes Rego s/nº Cidade Universitária, 50670-420 Recife, PE, Brasil

In the present communication we analyzed the levels of IgG1, IgG2, IgG3, IgG4 and IgE isotypes to soluble egg antigen of Schistosoma mansoni by ELISA in individuals from an endemic area for schistosomiasis in Northeast Brazil. The analysis was performed before and after treatment to evaluate the age-dependent pattern, and to identify differences in the reactivities to antigens. Our results suggest that schistosomiasis treatment would not interfere with this sort of immune response.

Key words: schistosomiasis - antibodies - treatment

Analysis of antibody responses to diferent antigens in patients' sera shows that the slow development of immunity to reinfection after treatment of Schistosoma infection is partially atributable to the continued presence of blocking antibodies in susceptible individuals, particularly IgG4 and IgG2 (Demeure et al. 1993). The role of IgE in several imune mechanisms against the parasite has been described in vitro, suggesting that these mechanisms might be involved in protection against human schistosomiasis (Capron et al. 1999). The levels of IgE antibodies to $S$. hematobium, mainly against adult worms, increased progressively with the age of the patient and were related to resistance to reinfection after chemotherapy (Hagan et al. 1991). The influence of $\mathrm{IgE}$ in immunity to $S$. mansoni reinfection has also been reported by other authors (Dunne et al. 1992, Rihet et al. 1992, Demeure et al. 1993).

We have previously evaluated the influence of antibodies of the isotypes $\operatorname{IgE}$ and $\mathrm{IgG} 4$ on the resistance and susceptibility to infection by $S$. mansoni in human populations living in two contiguous endemic villages (Itapinassu and São Joaquim) in Northeast Brazil by using soluble egg antigen (SEA) and soluble worm antigenic preparations (SWAP) in a immunenzymatic assay (ELISA). An association between age and levels of IgE schistosome-specific antibodies was found. The age-IgE profile followed that expected for an antibody involved in resistance to infection (Gomes et al. 1998).

This work received financial support from $\mathrm{CNPq}$, Facepe, and WHO.

${ }^{+}$Corresponding author. Fax: +55-81-3453.2449. E-mail: yara@cpqam.fiocruz.br

Received 18 June 2002

Accepted 15 August 2002
In the present communication we extended our previous studies, analyzing the levels of IgG1, IgG2, IgG3, IgG4 and IgE isotypes to SEA, in 58 patients from São Joaquim village, in order to evaluate the patterns of antibodies responses before and after treatment. The procedures followed were in accordance with the ethical standards on human experimentation.

Parasite burden was measured in stool specimens by the Kato-Katz method, and water contacts were evaluated by a specific questionary. Blood was obtained by venipuncture, before treatment and six months after treatment with oxamniquine $(15 \mathrm{mg} / \mathrm{kg}$ for adults and $20 \mathrm{mg} / \mathrm{kg}$ for patients under 15 years old), and serum stored at $-20^{\circ} \mathrm{C}$ until use. SEA was obtained using standard procedures (Gazzinelli et al. 1983). This preparation was dialyzed against distilled water and the protein concentration determined by the method of Lowry et al. (1951). IgG1, $\mathrm{IgG} 2$, IgG3, IgG4 and IgE antibody response to SEA was evaluated by ELISA (Hagan et al. 1991) using mouse monoclonal anti-human IgG1, IgG2, IgG3, IgG4 and IgE (Fc fragments). Assays were developed using horseradish peroxidase-conjugated rabbit anti-mouse IgG. Statistical analysis was performed using the software EPIINFO V 6.04 .

Before treatment, IgE and IgG4 anti-SEA antibody levels were more elevated than IgG1, IgG2, and IgG3 (Fig. 1). These antibody levels tended to increase after treatment (Fig. 2) suggesting stimulation of the antibody response due the drug effects or antigens exposure due to parasite damage. Although the intensity of the antibody response apparently increased after treatment, the age-dependent pattern of antibody response was very similar. The peaks of $\mathrm{IgE}$ and $\mathrm{IgG} 4$ antibody response were clearly in the 1019 year age group. In contrast, changes in the levels of the other isotypes analyzed were not so apparent. We have also analyzed antibody responses before and after treatment, using SWAP (data not shown). In general, the response was similar to that observed against SEA: IgG4 


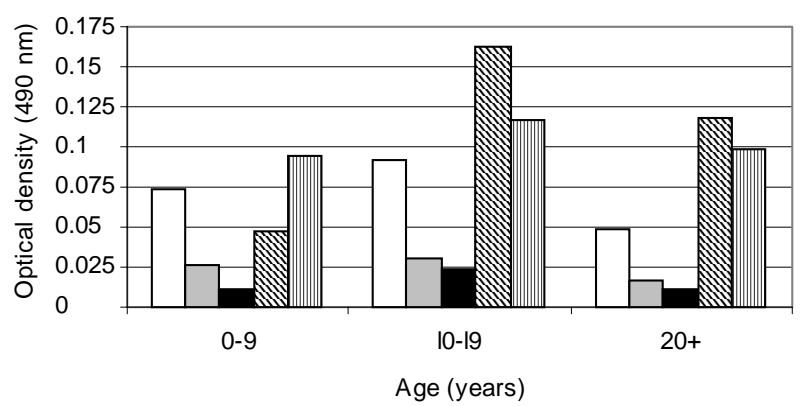

$\square \lg G 1 \square \lg G 2 \square \lg G 3$ \& $\lg G 4 \operatorname{m~} \lg E$

Fig 1: antibody isotype responses to soluble egg antigens of Schistosoma mansoni before treatment in patients living in an endemic area.

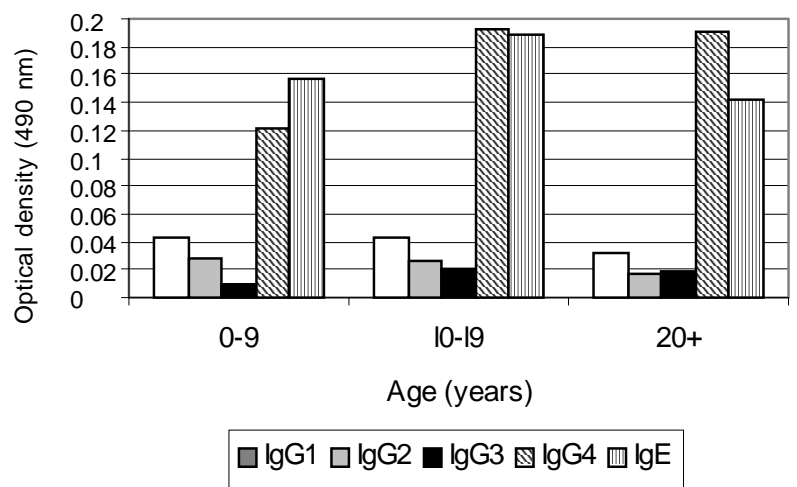

Fig. 2: antibody isotype responses to soluble egg antigens of Schistosoma mansoni after treatment in patients living in an endemic area.

antibodies were the most elevated, and the levels of antibodies were maximal $(\mathrm{p}<0.05)$ in young adults $(15-19$ years). Nonetheless, before treatment the first peak of $\operatorname{IgG} 4$ occured at a younger age range (10-14 years), in comparison to the humoral response observed after treat- ment, suggesting that treatment interferes with the production of $\mathrm{IgG}$ antibodies.

As IgE anti-parasite antibodies have been implicated as protective, our results suggest that schistosomiasis treatment would not interfere with IgE dependent protective immunity. Nevertheless, one should notice that, in addition to IgE antibodies, potentially blocking IgG4 antibodies, were also increased after treatment, peaking at the some age-group.

\section{REFERENCES}

Capron A, Dombrowicz D, Capron M 1999. Regulation of immune response in experimental and human schistosomiasis: the limits of an attractive paradigm. Microbes Infect 1: 485-490.

Demeure C, Rihet P, Abel L, Quattara M, Bourgoirs A, Dassein AJ 1993. Resistance to Schistosoma mansoni in humans: influence of the $\mathrm{IgE} / \mathrm{IgG} 4$ balance and $\mathrm{IgG} 2$ in immunity to reinfection after chemotherapy. J Infec Dis 168: 1000-1009.

Dune DW, Butterworth AE, Fulford AJC 1992. Immunity after treatment of human schistosomiasis: association between $\operatorname{IgE}$ antibodies to adult worm antigens and resistance to reinfection. Eur J Immunol 22: 1483-1494.

Gazzinelli G, Katz N, Rocha RS, Colley DG 1983. Immune response during human schistosomiasis mansoni. X. Production and standardization of an antigen-induced mitogenic activity by peripheral blood mononuclear cells from treated but not active cases of schistosomiasis. J Immunol 130: 2891-2895.

Gomes YM, Gomes FC, Furtado VC, Teixeira KM, Souza WV, Abath FCG 1998. IgE and IgA antibodies in subjects reinfected with Schistosoma mansoni in a endemic area of Northeast Brazil. Mem Inst Oswaldo Cruz 93: 183-184.

Hagan P, Blumenthal UJ, Dunne D, Simpson AJG, Wilkins HÁ 1991. Human IgE, IgG4 and resistance to reinfection with Schistosoma haematobium. Nature 349: 243-245.

Lowry OH, Rosebrouch NJ, Farr AL, Randall RJ 1951. Protein measurement with the Folin Phenol reagent. J Biol Chem 193: 263-275.

Rihet P, Demeure C, Bourgois A, Prata A 1991. Evidence for an association between human resistance to Schistosoma mansoni and high anti-larval IgE levels. Eur J Immunol 21: 2679-2686. 